\title{
"Laat die kindertjies na My toe kom...": kindwees in die wêreld van Jesus (Deel 1)
}

P J J Botha

(Unisa)

\begin{abstract}
"Let the children come to Me...": childhood in the world of Jesus (Part 1)
\end{abstract}

This study is the first part of an historical investigation into the conditions and experiences of childhood in first-century Palestine. Aspects of family life, birth and early childhood are discussed.

\section{INLEIDING}

Seker een van die bekendste uitsprake van Jesus is die uitnodiging dat die "kindertjies" nie verhinder moet word om na Hom toe te kom nie (Mk 10:13-16; Mt 19:13-15; Lk 18:15-17)'1.

Wat hierdie betrokke tekste betref, is daar al baie geskryf ${ }^{2}$. Die perikope word meestal gelees in die sin dat Jesus hier 'n "gelykenis" in dade uitbeeld, om te wys dat redding aan die nederiges behoort ${ }^{3}$. In hierdie trant word soms beklemtoon dat 'n radikale "omkeer" hier ter sprake is ${ }^{4}$. Jeremias 5 skryf nogal treffend oor hoe die dissipel 'n kind moet word, iemand wat weer 'abba kan sê. Derrett ${ }^{6}$ is van mening dat Jesus die scenario van Jakob wat sy seuns seën, toe-eien vir sy eie eskatologie: Jesus se "familie" is (letterlik) erfgename van God se "land" (koninkryk).

Daar is egter 'n belangrike vraag wat eers gevra moet word, naamlik die van konteks en historiese verstaan. Hoe was dit om 'n kind te wees in eerste-eeuse Galilea of Jerusalem? Het ouers destyds dieselfde opgetree as vandag? Was hulle lief vir hulle kinders op dieselfde maniere as wat ons vandag is, of het kindersorg verreikend deur die eeue heen verander? Hoe het ouers oor hulle kinders gevoel, en wat was hulle opvattings oor kinders en jongmense?

Vra mens na die historiese situasie, na hoe mens die kinders self moet voorstel in mens se geestesoog, na húlle ervaring en na die volwassenes se beskouinge van hulle kinders, is dit opvallend hoe min aandag aan sulke vrae gegee word in Nuwe-Testamentiese en verwante studies. 
'n Historiese kyk na aspekte van mense se kinderjare is geen ligtelike taak nie. Die geskiedenis van kindwees is, om dit sagkens te stel, 'n nagmerrie'. Dat dit egter 'n belangrike vraag is, kan nie betwyfel word nie. Hoe kinders groot gemaak word, speel 'n beslissende rol in die ontwikkeling van persoonlikhede en volwassenheid. Trouens, die "objektiewe gegewenheid" van die werklikheid wat 'n mens belewe is die gevolg van die sosialisering wat ons as kinders ervaar het ${ }^{8}$. Hierdie sosialiseringsprosesse is nie a-historiese, onskuldige en immer-dieselfde gegewenes nie. Daar is ' $n$ lang en komplekse historiese verloop verbonde aan die ontwikkeling van kindersorg, opvoeding en sosialisering. Ons huidige (Westerse) begrip van kindwees is die produk van die opkoms van die burgerstand van Europa ${ }^{9}$. In die woorde van die Bergers ${ }^{10}$ :

"As the bourgeoisie triumphed as a class, so did its ideals of childraising. And as these ideals became institutionalized - in the law, the educational system, and in the thinking of individuals - a particular vision of childhood came to be taken for granted."

Die implikasie is dat ons doelbewus ingesteld moet wees om die antieke vorme van kindwees te kan raaksien. Dit is juis behoorlike historiese ondersoek wat ons gaan help om, nie net die wêreld van Jesus en die Nuwe-Testamentiese geskrifte beter te verstaan nie, maar ook om onsself beter te beskou en sinvolle selfkritiek te beoefen.

Wat die wêreld van Jesus betref, is daar 'n romantiese uitbeelding van kindwees in heelwat van die literatuur in omloop. Hiervolgens het die tipiese Joodse familie graag kinders begeer en was daar tere verhoudings tussen ouers en kinders; was daar - anders as in die "harde" Grieks-Romeinse wêreld - respek vir kinders; kinders het skoolgegaan, ensomeer ${ }^{11}$.

Daar is nogal ernstige probleme met hierdie beskouing. Dit word saamgestel deur 'n klomp bybelversies aanmekaar te flans met 'n paar aanhalings van antieke outeurs. Die "resultate" reflekteer 'n naïewe kyk na die literêre bronne en 'n onkritiese terugprojekteer van moderne waardes en/of persoonlike voorkeure ${ }^{12}$. Dat daar volgens voorkeure gelees word, met ander woorde willekeurig, kan geillustreer word met hoe Tasitus aangehaal word vir "Judaïsme" se siening oor kinders. Byvoorbeeld13:

"The Roman historian, Tacitus, testifies that child exposure was unkown among Jews and that 'they regard it as a crime to kill any late-born child'".

In sy Historiae (5.5) verduidelik Tasitus kortliks die kerneienskappe van die Judeërs se geloof. Die godsdiens van die Judeërs, volgens Tasitus, is 
verkramp, gemeen en verfoeilik ${ }^{14}$. Trouens, so eng en fanaties is hulle dat die eerste les wat mens moet leer om een van hulle te word, is om alle gode te verag, jou land te ontken en ouers, kinders en familie te minag. Hoe groei hulle getalle dan? Hulle verbied kindermoord. En die rede? Dit is beter om in oorlog te sterf of onder die hand van die teregsteller sulkes se siele is onsterflik. Eintik sê Tasitus niks oor Judeërs se opvattings oor kinders nie; hy het duidelik baie beperkte kennis oor hulle en hulle opvattings. Dat hulle nie kindermoord pleeg nie is 'n illustrasie van hoe ernstig hulle is, volgens Tasitus, om eerder vir hulle geloof te sterf, 'n geloof wat maar liewers nie te hoog aangeslaan moet word nie.

Die onkritiese beskrywings van aspekte van kindwees in die destydse wêreld wat ons in baie navorsing vind, het waarskynlik 'n oorsprong in wat ons as 'n soort van "belangeloosheid" kan beskrywe's. Wie dink tog dat die geskiedenis van kindwees regtig belangrik is? Margeret Mead wys daarop dat "kinders" maar 'n onlangse onderwerp in die menswetenskappe is ${ }^{16}$. Hierdie "belangeloosheid" reflekteer 'n ernstige tekort aan aandag aan die "minderes" van die geskiedenis. Daar is ongelukkig genoeg waarheid in die beskuldiging dat vroue, kinders en armes al te maklik beskou word as maar net nóg vroue, kinders en armes: tydlose kreature (nie mense nie) waar die een netsowel die ander kan wees ${ }^{17}$. Geskiedenis word meestal en nogal in die Bybelwetenskappe ook - benader as "an account of the doings of the great"18. Alhoewel daar nog altyd belangstelling was in breëre sosiale en ekonomiese faktore wanneer dit by geskiedenis kom, kan ons nie ontken dat die hoofsaak van geskiedenis-interpretasie bly vassteek het by die politieke aktiwiteite van die aristokrasie nie ${ }^{19}$.

Die belangrike rede hoekom ons meer omvattende en inklusiewe geskiedskrywing moet beoefen is ter wille van verstaan. Sonder so 'n verbreding kan daar nie regtig van historiese insig gepraat word nie. Immers, dit is juis óns taak om die "werklike" mense van die verlede te beskerm teen die "enormous condescension of posterity" 20 .

Die dramatiese andersheid van antieke kindwees word nogal goed verwoord deur Augustinus. "Is daar enigiemand," vra hy, "wat as daar gekies moet word tussen die dood of om weer 'n keer kind te wees, nie vanuit angs vir die tweede opsie sal verkies om te sterf nie?"21. Augustinus, wat vir sy tyd sekerlik nie 'n ongewone opvoeding gehad het nie, vermeld die talle maniere waarmee kinders geteister word "om hulle moedswilligheid te bedwing". Onder andere noem hy die "stok, die leerband en die lat" waarmee die "geliefde kind getem word" (De civitate Dei $22.22)^{22}$. Augustinus self was 'n voorstander van 'n goeie geseling (met 'n sweep - flagellat) om gehoorsaamheid by seuns te bewerkstellig23. 
In hierdie artikel bied ek 'n verkenning van kindwees in eerste-eeuse Palestina, hoofsaaklik om die lewens van die "gewone" mense rondom Jesus te belig.

\section{FAMILIES}

Dit is belangrik dat ons aandag gee aan die begrip "familie" want dit bied ons 'n raamwerk om ander aspekte te interpreteer - sake waarvoor ons nie altyd oor voldoende gegewens beskik nie, of waaroor die data dubbelsinnig is.

"Familie" dui in ons wêreld 'n mammie, pappie en kinders aan. Destyds het die begrip 'n wyer konnotasie gehad: mense wat as gevolg van afkoms of troue verwant was (kin), 'n geslagslyn of huis (lineage) en diegene wat saam onder een dak bly, insluitende werkers, slawe en nieverwante persone (household) maak almal saam 'n "familie". Die antieke familie kan gesien word as 'n "knooppunt" van aldrie genoemde aspekte ${ }^{24}$. Gegewe voldoende rykdom en status, kon 'n "familie" honderde persone omvat. Binne 'n familie was gesinne egter klein.

Dis veral die kwessie van geslagslyn of "naam" wat dikwels belangrik geag is, selfs belangriker as individuele lede van 'n "familie". Die familiegesentreerdheid van die antieke wêreld moet letterlik opgevat word: die familie is die sentrum van die lewe - nie net in die sin van lede wat met mekaar te doen het nie, maar as die betekenisgewende matriks vir die hele lewe ${ }^{25}$. Familie-eer was meer as net familietrots (wat ons goed ken); dit was 'n kwessie van "bloed", letterlik lewe en dood.

\subsection{Dit gaan goed met die man wat sy pylkoker so gevul het!}

'n Verdere aspek, belangrik vir die doeleindes van hierdie studie, is die feit dat die antieke "familie" die kern-eenheid van produksie was. In 'n preindustriële, agrariese wêreld met 'n lae vlak van tegnologiese ontwikkeling, is mensekrag die hoofbron van werkkrag. Daar is dus altyd te min hande. Kinders is ' $n$ bron van energie (arbeid) en dit is hoe daar oorleef word ${ }^{26}$.

In so 'n wêreld word kinders, onder normale omstandighede, gewoonlik verwelkom. Die wyer demografiese konteks moet ook in berekening gebring word ${ }^{27}$. Die sosiale, politieke en ekonomiese lewe van 'n bevolking met ' $n$ gemiddelde lewensverwagting van twintig jare is in talle opsigte totaal anders as die van 'n bevolking wat verwag om sestig of sewentig jaar oud word. Ons (Westerse) lewensverwagting het meer as verdriedubbel sedert die antieke tye ${ }^{28}$. Destyds was die bevolkings- 
verspreiding soos 'n piramiede; groot getalle jongmense (en kinders) en min bejaardes. Nie dat gesinne noodwendig groot was nie; met die uitsondering van die welaf families het die hoë sterftesyfer gesorg dat hoë geboortesyfers nie gelei het tot groot gesinne nie ${ }^{29}$.

Die behoefte aan en verwagting van "talle" kinders was dus 'n sterk waarde. Alhoewel dit fiksie is, gee die Proto-evangelie van Jakobus, 'n tweede-eeuse geskrif, ons 'n goeie indruk hiervan ${ }^{30}$. In hierdie vertelde wêreld word Maria se pa, Joakim, nie toegelaat om eerste sy offer in die tempel te bring nie omdat hy nie kinders het nie. Nadat hy die geslagsregisters deursoek het besef hy dat hy die enigste onder al die "regver-

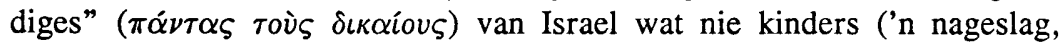
$\sigma \pi \varepsilon \rho \mu \alpha)$ het nie en gevolglik vlug hy die woestyn in (Protev Jak 1.1-3). Hy keer slegs terug na 'n engel aan hom verskyn. Anna, Maria se ma, wat reeds oor kinderloosheid gerou het en haarself verneder het, sien 'n mossie met kuikentjies, sug ten hemele en hef 'n klaaglied aan:

"Wee my!

Wie het my gemaak en wie het my gebaar?

Ek is gebore om 'n vloek vir almal te wees en voor die kinders van Israel.

Hulle het my uitgeskel en my getart en my uit die tempel van die Here uitgejaag".

(Protev Jak 3.1)

Vroue wat nie kon swanger word nie is verag. Elisabet, Sagaria se vrou en ma van Johannes die Doper, se uitspraak dat die Here na haar omgesien het deur haar "smaad onder die mense weg te neem" is insiggewend ( $\mathrm{Lk}$

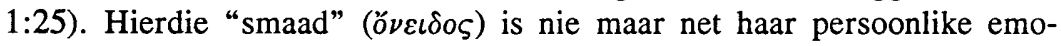
sionele onvergenoegdheid nie; om "onvrugbaar" te wees was geag die vrou se skuld, 'n belediging vir haar man, 'n (godsdienstige) aanklag teen haar man se familie en rede vir die gemeenskap om haar te verneder/minag ${ }^{31}$.

\subsection{Daar was omtrent vyfduisend mans ... afgesien van die vrouens en kinders}

Die blydskap wat gewoonlik vermeld word in verband met swangerskap moet reg begryp word. In eerste-eeuse Palestina was die vreugde gemik op die geboorte van seuns. "Seuns is geskenke van die Here" maar "die geboorte van 'n dogter is 'n verlies ( $\dot{\varepsilon} \lambda \alpha \tau \tau \dot{\omega} \sigma \varepsilon \iota)$ " 32 .

Vir só 'n wêreldbeeld bestaan 'n familie in terme van die manlike afstammelinge. Waar daar nie seuns gebore word nie, moet die "vader" tydig optree; deur 'n ander of deur verdere huwelike of deur aanneming 
moet daar 'n seun wees anders "sterf" die familie. 'n Huwelik dien die familie en is nie 'n uitdrukking van die twee jongmense se strewe na vervulling nie. Dit was van die allergrootste belang vir 'n gesin om minstens een seun te hê. Seuns kon erf (en nuwe seuns maak). 'n Seun kon die familie-eer, die "naam" beskerm en laat "voortleef", maar veral kon die erfenis net behoue bly as daar seuns was. Seuns was verantwoordelik vir die begrafnis en roudienste ten opsigte van hulle ouers, en seuns was wetlik verplig om hulle ouers in hulle oudag te versorg. Let op die rede as 'n pa vir Jesus smeek om sy seun gesond te maak (Lk 9:38). Dat die kind siek is pla hom nie: "Meneer, ek smeek u, kyk bietjie na my seun, want hy is my enigste seun [wat na my kan omsien as ek oud is/die familie kan laat voortbestaan]."

Daardie wêreld was androsentries tot so 'n mate dat dit vir ons bykans onbegryplik is. ' $n$ Vrou se status, waarde, essensie, haar wese was geheel-en-al opgeneem in die "significant men" rondom haar. Alleenlik deur geboorte te skenk aan 'n seun kon sy haar posisie in 'n familie vestig; tot haar band met haar man was afhanklik van haar seuns.

\section{GEBOORTE}

Ouerskap is een van die mees basiese instinkte van mense - diep gesetelde en kragtige emosies is hier ter sprake. 'n Joodse egpaar in Rome, Maria en Amelius, se seun het gesterf toe hy twee jaar, twee maande en vyf dae oud was. Op die seuntjie se herdenkingsinskripsie sê Amelius en Maria dat hy 'n "dierbare" ( $\gamma \lambda v \kappa v \tau \alpha \dot{\alpha} \tau \omega-$ soet), "onskuldige en vrome kind" was ${ }^{33}$. Dat mense lief was en is vir hulle kinders is een van die mooiste menslike eienskappe. Maar die feit van die emosies sê niks oor die konteks en uitlewing daarvan nie $^{34}$.

\subsection{Terwyl hulle daar was, het die tyd gekom dat haar kind gebore moes word...}

Destyds het mense nie eintlik voorberei vir die "groot dag" nie ${ }^{35}$. Wanneer die kraampyne begin was die mening dat die mammie behoort te lê; slegs ander vroue word by haar toegelaat ${ }^{36}$. Soms, met 'n moeilike bevalling is die vrou op 'n houtraam vasgemaak, vertikaal opgetel en op 'n bondel stokke laat val, of 'n hoenderhen is aan haar vasgemaak; die bedoeling was om 'n uitgerekte kraam te verkort.

Vir die laaste fase van kraam sit die vrou. Die rabbynse literatuur verwys na 'n spesiale kraamstoel; waar dit nie beskikbaar was nie het die vrou wat kraam op die knieë van 'n sterk vrou gesit. Onder die gewone 
mense (soos, waarskynlik, in die Galilese kleindorpies) is sy gemaak sit op twee groot klippe. Die vroedvrou was gewoonlik 'n ouer vrou, iemand wat nie met wol gewerk het nie (spin en weef maak mens se hande grof en vol eelte).

$\mathrm{Na}$ die geboorte is die kindjie ondersoek. Terwyl die mammie in haar sittende posisie wag, moet besluit word of die kind groot gemaak gaan word. 'n Belangrike faktor is natuurlik geslag37; maar die moeder se gesondheid, en die kind se eerste huil is ook in ag geneem. Dan word die ledemate, gewrigte, vel, mond, neus, ore en oë ondersoek.

Die naelstring is deurgesny nadat die baba ondersoek is. Die "dokters" (dit wil sê, die destydse "wetenskaplike" beskouing) het 'n staalmes, of minstens ' $n$ geslypte ysterlem aanbeveel; maar baie vroedvroue het 'n klipmes verkies. 'n Skerp riet of 'n droë broodkorsie is ook gebruik.

Kinders met onaanvaarbare gebreke - en ongewenste kinders - is waarkynlik so van ontslae geraak: die naelstringetjie is "verkeerd gesny" 38 .

Daar word nogal dikwels veel gemaak van die gedagte dat aborsie en veral te-vondeling-legging (dit wil sê kinder-weggooi) ${ }^{39}$ 'n GrieksRomeinse verskynsel is, en nie onder Joodse mense voorgekom het nie en, deur assosiasie, ook nie onder Christene nie ${ }^{40}$.

So eenvoudig was die saak egter nie. As te-vondeling-legging ongekend was in Joodse kringe sou die vermanings mos nie sin gemaak het nie $^{41}$. Vondelinge was 'n bekende verskynsel in Joodse kringe gewees (bv m.Qiddushin 4.1-2, m.Makhshirin 2.7). Volgens die rabbis is daar sekere beperkinge op die godsdienstige rolle wat vondelinge kan beoefen, en is hulle onderworpe aan beperkte huweliksregte, maar as die opgetelde baba besny is, behoorlik verbind is, ' $n$ amulet (as beswering teen duiwels) aan die kleintjie gebind is, die baba in 'n boom vasgemaak is (ter wille van wilde diere) of by 'n sinagoge in 'n sentrale gebied (afgeleë geboue is lêplekke vir geeste), of op bewegende water gelaat is, kan veronderstel word dat die kind uit 'n "goeie" familie kom en behoort uitsonderings oorweeg te word. Alhoewel buite-egtelike kinders ter sprake is, is dit veral armoede en honger wat ouers hiertoe dryf. Ouers kan 'n kind terugeis 'n erkenning is voldoende - maar sodra die baba "opgetel" is, verval alle aanspraak behalwe ten tye van hongersnood (cf p. Qiddushin 73a-b) ${ }^{42}$.

Eintlik is dit 'n bedrieglike vereenvoudiging om te beweer dat die "Joodse wêreld" (of die "Christelike era") 'n "beter bedeling" ten opsigte van vroue en kinders gebied het. Tereg wys Derrett ${ }^{43}$ daarop dat selfs al sou dogters nie weggegooi gewees het nie, daar in die praktyk, wat betref die houdings teenoor en behandeling van vroue en kinders maar bittermin 
verskil tussen Joodse en Grieks-Romeinse families was. Onthou dat dié volksheld, Abraham (dié vader van dié volk) nie geskroom het om 'n jong mammie met hulle (sy eie) kind weg te jaag nie.

Die mees veelseggende aspek is egter die besonder min aandag wat aan weeskinders, ongewenste kinders en aangenome kinders in die rabbynse korpus gewy word ${ }^{44}$. Dit is onvoorstelbaar dat hierdie (en verwante verskynsels) nie in die wêreld van die rabbis bestaan het nie. Immers, dit is 'n konteks wat behep is met nageslag en bloedlyne, waar veelwywery beoefen is, waar slawerny bestaan het en waar broers die leviraatshuwelik kon afdwing.

Die waarskynlikste verklaring is die eenvoudigste: soos in talle ander opsigte het baie antieke Joodse families, wat betref ongewenste kinders, opgetree nes die tipiese Grieks-Romeinse familie - pragmaties ${ }^{45}$. Die punt is nie of dit gebeur het nie (ongetwyfeld het dit), of selfs hoe dikwels nie; maar dat daardie mense kinders as besittings geag het.

Daar mag dalk (openbare) veroordeling van babamoord en blootstelling gewees het, maar die verkoop van kinders, en veral van dogters was heeltemal aanvaarbaar. Dit is maar net nog een van die alledaagse dingetjies wat "reg" gedoen moet word. Op hierdie punt moet die kwessie van slawerny opgehaal word.

'n Beduidende aantal kinders is destyds of as slawe gebore, of is in slawerny verkoop. Oor hulle omstandighede, hoe hulle groot gemaak is en tot watter mate hulle slegter (of beter) as vrygebore kinders daartoe af was, weet ons bittermin. Waarskynlik, wat betref die eerste paar lewensjare, was daar nie veel onderskeid nie (onthou, hierdie slawekinders verteenwoordig 'n "belegging") - maar dit sou net realisties wees om die sorg en aandag van die "eersgebore seun" nie as die standaard vir die ander kinders en veral nie vir die slawekinders te sien nie.

Heelwat Joodse families het natuurlik in daardie tye slawerny "van onder af" ervaar. Weens die politieke geskiedenis van die Romeinse era is aansienlike getalle Joodse families weggevoer vanuit Palestina. Maar nie net het Jode slawe geword van Romeinse heersers nie, hulle het ook (in aansienlike getalle) slawe geword van ander Jode ${ }^{46}$. 'n Slaaf is naturlik "gereedskap" vir die meester/eienaar - sy lewe is 'n verlenging van die meester se wil en "hande" as't ware. Die gereedskap wat jong meisies as slavinne moes wees is vanselfsprekend; hulle is verkoop om byvroue te word.

As ons vra hoe dikwels hierdie praktyk plaasgevind het, is dit moeilik om betroubare gegewens te vind. Die antwoord lê waarskynlik gebonde aan omstandighede. 'n Dogter kon verkoop word totdat sy twaalf 
jaar oud is (m.Ketubbot 3.8 - haar pa besit haar seksualiteit tot dan). Die koop en verkoop van slawe val in dieselfde kategorie as grond en diere; dit wil sê, duur items met langtermyn implikasies wat nie verhandel word tydens die gewone kleinmark-geleenthede waar landbouprodukte en ander alledaagse items verhandel is nie ${ }^{47}$.

Wat was die omstandighede waarbinne kinders verkoop is? Omdat ons oor mense praat, is die moontlike redes waarskynlik eindeloos ${ }^{48}$. Ek vermoed dat dit meer voorgekom het in moeilike tye; soos uitgebeeld in die volgende:

"Ons moes geld leen om aan die koning die belasting op ons lande en ons wingerde te betaal. Ons en ons volksgenote, hulle seuns en ons seuns, is tog één, maar óns moet van ons seuns en ons dogters laat slawe word. Van ons dogters is al klaar slawe, en ons kan daar niks aan doen nie, want ons lande en ons wingerde is in ander se hande" (Nehemia 5.4-5; vergelyk 2 Kon 4.1).

Met 'n kind se geboorte, het haar of sy familie deur een of twee beslissings die kind se hele lewe dramaties bepaal. Hierdie besluite is fundamenteel beïnvloed deur die siening dat kinders "onderworpe is", hulle word "besit", hulle is nog nie mens nie. Sekere sosiale en godsdienstige instellings was duidelik belangriker as enige enkeling se lot.

Destyds moes 'n kind deur die vader erken word: die opvatting was dat die erkenning van die vader ("kyk, mý kind") die kleintjie legitiem maak. (Hierdie, vir ons vreemde beskouing, is die praktiese gevolg van die sogenaamde patria potestas, die reg van die sentrale mansfiguur oor lewe en dood binne die familie ${ }^{49}$. Mense het destyds nie kinders "gehad" nie, maar kinders "geneem" en "grootgemaak". Die "legitimisering" (erkenning/aanneming) was die "begin" van lewe, en nie geboorte as sulks nie. Moeders het nie veel sê gehad in hierdie besluit nie - dit wil sê, nie veel direkte inspraak nie. Mens sidder as die impak van verskuilde en onderdrukte gevoelens in ag geneem word.

\subsection{In doeke toegedraai...}

Net na geboorte is die baba gewas en dan met sout (of 'n mengsel van olyfolie en sout) ingevryf - so belangrik is die soutsmeerdery dat die rabbis dit toegelaat het selfs al is die baba op 'n Saterdag gebore (p.Shabbat 129b). Die oortuiging was dat die sout wat die vroedvrou op die baba invryf die dun, sagte velletjie van die baba versterk en die kind se persoonlikheid sterker maak. Daar is 'n Semitiese gesegde wat sê dat ongesoute kinders 'n swak en giggelrige karakter verkry50. Immers, almal weet dat sout help om dinge te preserveer; hoe meer sout ingevryf is, hoe 
langer leef die kind. Heuning en gis egter, soos almal geweet het, bevorder verrotting, en is die teenoorstaande van sout. Sout het ook bo-natuurlike kragte. Dit is hoekom dit saam met offers gebruik is (kyk bv Lv 2.13). Sout kon ook duiwels afskrik ${ }^{51}$.

Nadat die baba gesout is, is die kleintjie baie styf "met doeke toegedraai". Die toedraai is eintlik verbind. Plankies, stokke en selfs uitgeholde stompe is gebruik tydens hierdie "in doeke vasbind". Vir etlike maande het die kindjie glad nie beweeg nie. Die opvatting was dat beweging sleg is vir ' $n$ baba, en veral seuns moes baie styf in lappe toegedraai word. Die toedraaiery is so gedoen dat al die ledemate reguit was, en veral die ruggie moes plank-reguit wees. Destyds was 'n regop houding een van die onderskeidings tussen mense met status en ander soos slawe.

Die handjies is oopgespalk (nie in vuisies nie), met reguit vingertjies. Gewrigte, veral die polse, enkels en elmboë is besonder styf vasgebind. Die beentjies is van die tone af boontoe vasgebind, met ekstra druk om die voetjies reg te vorm. Die armpies word dan langs die lyfie gestrek en weer van kop tot tone verbind, met 'n doek tussen die boudjies en die lappe. 'n Behoorlike omswagteling se windsels kon drie tot vier kilogram op sig self weeg!

In arm huishoudings, waar daar min tyd en nie juis ekstra hande was nie, is waarskynlik net die babatjie se bolyfie en voetjies verbind en die bene en boude oopgelos. Dié styl van omswagtel was sekerlik by heelwat families in gebruik, maar die algemene opvatting was dat 'n baba wat behoorlik toegebind is, die beter manier van babasorg was.

Dit sou interessant wees om te spekuleer oor die impak van sulke "vasbind" van kleintjies en die gepaardgaande gebrek aan beweging52. 'n Behoorlike omswagtelling kon tot twee ure duur, maar die voordele vir die volwassenes was aansienlik - 'n toegebinde baba is uiters passief, huil min, slaap geweldig baie en raak oor die algemeen teruggetrokke ${ }^{53}$. Mens kan ook aanneem dat hierdie praktyk 'n rol gespeel het in die vestiging van 'n passiewe uitkyk op die lewe en die gedweë aanvaarding van eksterne gesag.

Die verbande is van wol gemaak (linne is nie gebruik om babas te verbind nie want linne krimp wanneer dit nat word). Wol is grof; stel die baba in mens se geestesoog voor: die velletjie rooi en geïrriteerd, die lappe wat styf vasgemaak is, is deurdrenk met urine en ekskrement. Elke nou en dan is die baba vir 'n dag of wat in net 'n soort onderhempie geklee sodat die seerplekkies kan gesond word. Vir sere en skaafplekke is allerhande "boererate" gebruik, soos fyngestampte rooigrond. 
Die verbande is vir so om-en-by ses tot agt maande en dikwels selfs langer gebruik. Biskop Zeno van Verona, in 'n preek vir dopelinge, kontrasteer "aardse" moederskap met die kerk as moeder:

nou neem ons Moeder julle aan ... [anders as] toe julle gehuil het, bemors en toegedraai in smerige lappe. Nou is julle Moeder vol vreugde en is julle bly ... sy lig julle op nie uit stinkende wiege nie maar uit heiligdomme geurig met die reuk van die heilige altaar ${ }^{54}$.

Dis duidelik dat mense nie destyds geskroom het om liggame te manipuleer nie. Plat neuse is opgelig, krom voetjies is reg gebind, holtes in die ruggie is reggedruk met spalkies ensomeer. Daar was sterk vooroordeel teenoor linkshandigheid; wanneer die lyfie losgemaak word, is die regterhandjie eerste gedoen. Met teregwysings en strafmaatreëls is kinders geleer om hulle regterhande te gebruik.

Wanneer die kleintjie gebad word, word die baba se blaas gedruk om urinering aan te help - om latere benatting te verminder. Babas is verkieslik nie te veel gebad nie, en kleintjies ('n jaar of so) nog minder. Die Griekse gebruik om 'n baba met koue water te was is uiteraard as "heidens" en "uitheems" beskou; so ook die opvatting van die Romeinse dokters dat 'n baba nie te dikwels in warm water gebad moes word nie want twee of drie keer per week is genoeg (hierdie gebruike verwys na die kinderoppassers van vooraanstaande Romeinse huishoudings). Die (wetenskaplike) verklaring vir nie te veel bad nie was dat alles uit vier elemente opgebou is (water, vuur, lug, grond) en die ideaal (gesondheid) is 'n balans. Vrouens het te veel vog in hulle lywe (daarom bloei hulle elke maand); babas ook, daarom is hulle so sag en ongevormd. Te veel bad sal die lyfies nog sagter mak. Op die platteland, so vermoed ek, het pragmatiese beslissings die deurslag gegee: die beskikbaarheid van water en tyd, en die eise van die familie. Voorskrifte vir die bad van babas het gewissel van na die eerste week en dan weer as die kind loop, tot een keer 'n week vir die eerste maand en dan elke maand. Mammies was oortuig dat 'n kind moet vra om gewas te word. Indien die baba se ouer broers met geboorte gesterf het, is daar veral gekeer dat die baba gebad word. Smerigheid is ook beskerming teen die sogenaamde "bose oog" 55 .

Kleintjies is geborsvoed vir twee tot drie jaar. Soogvroue was baie keer gebruik, veral in welaf huishouding waar 'n slavin of 'n ander gehuurde vrou gebruik is. In ander huishoudings het van die ander getroude vroue sommer ingestaan. As 'n troosding is babas 'n lap gegee met heuning (of granaatsap - iets soets) om aan te suig. Dit was ook nie ongewoon dat ouma die kind aan haar bors troos nie.

Bok- en skaaphorings, maar ook bootvormige mandjies is gebruik as kinderbottels; sommige terracota suigflesse het ook sommer as 
"towerbakkies" (magic bowls) gedien56. Kameel-, bok-, skaap- en koeimelk is vir die kleintjies gegee, maar koeimelk was maar skaars in Palestina (kleinboere beskou beeste as duur, moeilik beheerbare en arbeidsintensiewe diere ${ }^{57}$ ). Kleintjies is ook sommer direk aan die spene van bokke laat suig. Maagderm-ongesteldhede en oogkwale was alledaagse verskynsels (toestande wat aangehelp word deur wan- en ondervoeding).

Wanneer dit tyd word om die kleintjie te speen word 'n bitter mengsel aan die tepel gesmeer. Babas is in elk geval baie gou "vaste" kos gevoer, aanvanklik wat eers deur ander gekou is, maar spoedig enigiets wat vermoed word die baba begeer dit. Die fase waartydens kinders gespeen is, was allerweë beskou as 'n gevaartyd: talle olikhede, groot ongelukkigheid en spanning 58 .

Galenus se idee van goeie kleutersorg is:

Ouer kleintjies [een tot twee jaar oud?] kan gehoorsaam gemaak word deur houe, dreigemente, skrobberings, en vermanings. Daar is twee tye in die dag wat geskik is vir die was en massering van kleintjies. Die beste tyd is wanneer hulle in die oggend wakker word en na 'n rukkie se speel vra vir kos. Dan is dit die beste geleentheid om die gewoontes in te dril wat sal sorg dat hulle liggame gesond en mooi sal bly en dat onderdanige en gehoorsame karakters gevestig word: maak dit duidelik dat daar geen kos gegee sal word nie alvorens hulle sonder teenstand gemasseer en gewas is. (Oribasius, Libri Incerti 17)

Hierdie is waarskynlik 'n goeie weergawe van alledaagse praktyke destyds.

\subsection{In die mag van 'n duiwel...}

Vir die meeste mense van die eerste-eeuse wêreld was die daaglikse lewe van tyd tot tyd maar 'n gevaarlike belewenis. Mens moes maar voortdurend voorsorgmaatreëls tref teen kwaai geeste en moeilike duiwels; 'n bietjie moeite op 'n gereelde grondslag kon jou baie smart spaar.

Die eerste week na 'n bevalling was vir die vroue van destyds 'n vreesaanjaende tyd. Vir sewe dae moes die kleintjie dag en nag onder oë gehou word, want in dié tydperk het die bose geeste gelê en loer. In 'n onbewaakte oomblik word die kleintjie maklik in besit geneem en word die baba siek of mal. Immers, meer as 'n kwart van babas wat gebore is het binne die eerste paar maande van hulle lewens gesterf $f^{59}$.

Allerlei mengsels wat in spesiale kommetjies geplaas is ${ }^{60}$, rites, amulette, beswerings en so meer is ingespan om die ondinge te bekamp. Lilith (die naggees, Jes 34.14 ) het vroue in kraam aangeval, maar sy het veral belang gestel in pasgebore babas: sy het hulle bloed gedrink en dan 
hulle murg uitgesuig. Lilith ${ }^{61}$, met haar lang, los hare het afvallig geraak omdat sy nie aan Adam onderdanig wou wees nie en sedertdien het sy mag oor seunsbabas vir die eerste week en oor dogterbabas vir die eerste drie weke - behalwe as sekere amulette en engelname by die baba gehou word. Sy gryp ook mans wat alleen slaap (Sigmund Freud sou nogal belang gestel het in hierdie vrees...). Tussen die Qumrandokumente is daar 'n eerste-eeuse gebed/lied oor God se Mag voor wie alle kragte vreesbevange raak, insluitende die geeste van die engele wat verwoesting saai asook Lilith ${ }^{62}$.

Deur die eeue heen is kinders nog altyd geboelie met stories oor monsters, wilde diere, spoke en ander (onsigbare) bedreigings. Dio Chrysostomus skryf dat sulke verhale "uitgedink is tot die kind se voordeel, om die kind minder voorbarig en onregeerbaar te maak". Sulke drogbeelde, was die redenasie, is goed om kinders te dissiplineer wat betref eet en speel op die regte tyd63. Vanuit die kind se oogpunt, in 'n konteks wat bo-natuurlike magte as 'n werklikheid aanvaar, moes die wêreld dikwels 'n vreesaanjaende ervaring gewees het.

Naas die liliths $^{64}$ was daar nog honderde ander demone. Lix Tetrax, byvoorbeeld, steek goed aan die brand en versteur huishoudings: wanneer hy die kans kry seil hy in onder die hoeke van huise, dag of nag (Testament van Salomo 7.5). Bose geeste was in die lug wat mens inasem, in die water wat mens drink, in die vleis wat mens eet. Hulle het weggekruip in donker hoeke, en het saamgekoek op afgeleë plekke ${ }^{65}$. Die emosionele en psigologiese impak van hierdie soort van opvoeding moes enorm gewees het, en het sekerlik bygedra tot die ontwikkeling van allerlei angstoestande ${ }^{66}$ en waarkynlik ook fobië̈67.

'n Merkwaardige illustrasie hiervan is die lyfrok van 'n kind wat uitgegrawe is in die grotte van Nahal Hever, wes van die Dooie See naby En-Gedi68. Hierdie vonds dateer vanuit die Bar Kogba era. Aan die agterkant van die rokkie is soutkristalle en ander "medisyne" in verskeie bondeltjies ingeknoop, om die kind te beskerm teen hierdie onsigbare bedreigings. Drie sakkies keer siektes, vyf maak gesond en sewe hou sommer geeste ook weg (m.Shabbat 6.9; p.Shabbat 66b). Mense het ook gordels en halsbandjies gedra met sulke apotropiese bondeltjies daaraan vas.

\subsection{En die naam van die kind is...}

Die wêreldbeeld wat onsigbare wesens ernstig neem, is ook wat in ag geneem moet word by die naamgewing van kinders. 'n Mens se lot (destiny) kan sigbaar word op onverwagse maniere want daar is geheime 
betekenisse in alledaagse gebeure of verskynsels of handelinge opgesluit. 'n Onbedoelde woord, of onverwagse natuurlike verskynsel is sleutels nie net tot die toekoms nie maar ook tot die diepste geheime van mensself en andere. Die gewone lewe is vol van "tekens", simbole vir die wat oë het om te sien ${ }^{69}$.

Astrologie was 'n groot deel van mense se lewens ${ }^{70}$. Nommers (getalle) het allerlei magiese konnotasies gehad. Hierdie was 'n kultuur waar klanke ook nommers kon wees en woorde en name kon velerlei geheime verraai met 'n bietjie moeite ${ }^{71}$.

Dit volg dat persoonsname dikwels nie onskuldige benoemings kon gewees het nie. Kinders het name gekry om een of ander familie tradisie voort te sit; baie kinders is doelbewus of subtiel bewus gemaak van allerlei sinspelings of implikasies van hulle name. 'n Naam het maklik 'n gebeurtenis in die ouers se lewens weerspieël of 'n voorspelling rakende die kind se toekoms bevat. Soos in ander pre-industriële kulture het 'n naam dikwels gedien as aanduiding van persoonlikheid, of karaktereienskappe ${ }^{72}$. Wat ons, vandag, tuisbring onder konsepte soos identiteit en persoonlikheid is destyds dikwels verwoord met persone se name, en gekoppel aan mense se gewoontes en gebare. Uit ons perspektief gesien, kan ons sê dat hulle maklik "bestaan" en "identiteit" verwar het.

Ek verwys net kortliks na allerlei implikasies van so 'n belewenis van benoeming. Sonder ' $n$ naam word die klein mensie natuurlik juis nie as ten volle mens beskou nie. Dan moet ons die rol van self-vervullende profesie nie onderskat nie ${ }^{73}$. Die opvatting oor name reflekteer nie net 'n fatalistiese en magiese wêreldbeeld nie, maar hou dit ook in stand.

In die geval van seuns was die erkenning en naamgewing 'n groot en feestelike geleentheid, wat gewoonlik saam geval het met die seun se besnydenis, 'n week na sy geboorte. Vir meisies sou daar nie so iets gewees het. Dogters het hulle name maar met verloop van tyd gekry, gewoonlik so 'n twee of drie maande na geboorte (soms eers as hulle begin loop het) en gewoonlik by die ander vroue in die huishouding.

Dit is opvallend dat, geoordeel op die beskikbare gegewens, dogters maar selde dubbelname ontvang het, en ook nie - soos seuns dikwels teoforiese name nie. Die gegewens is natuurlik nie heeltemal betroubaar nie omdat daar in elk geval min oor en na vroue verwys word in antieke literatuur ${ }^{74}$. Die rol van teoforie is natuurlik omdat mens se naam nie net gedien het as bekendstelling tussen mense nie, maar ook tussen die engele en demone. 
Die status van kinders was destyds 'n dubbelsinnige saak. Twee fasette behoort beklemtoon te word. Eerstens, die veel besproke verskille van sogenaamde Joodse gesinslewe en aspekte van kindwees met die "heidense Grieks-Romeinse" leefwyse blyk baie problematies te wees. Die "Joodse" familie in eerste-eeuse Palestina was, wat betref struktuur, ideale en gesinsdinamika, vir alle praktiese doeleindes dieselfde as die van ander Mediterreense kulture. Tweedens moet daar gewaak word teen romantiserende uitbeeldings.

Dit is duidelik dat kindersorg destyds heelwat anders as vandag beskou is. Ons moet dit natuurlik verstaan as 'n onderdeel van die opvattinge en belewenisse van familie en veral vaderskap wat destyds gegeld het. Hoe 'n kind groot gemaak word is nie die willekeurige keuse van die ouers nie, maar word grootliks bepaal deur die kultuur waarvan hulle deel is ${ }^{75}$. Deur kindwees in die antieke te bestudeer, verkry ons besondere insig in die sosio-kulturele wêreld van destyds.

Die konklusie dat, vanuit óns perspektief bekyk, kinders tog geminag en misbruik is, kan egter nie ontduik word nie. Dit beteken nie dat ouers nie lief was vir hulle kinders nie ${ }^{76}$, alleenlik dat dit 'n ander wêreld was, en dat ons net nog meer toegewyd moet reflekteer oor wat behoorlike kindersorg dan wel behels.

In 'n volgende artikel (deel 2) verken ek verdere aspekte van kindwees, veral wat betref sosialisering en opvoeding.

\section{NOTAS:}

1 Allerweë word Markus $10.14-15$ as 'n redelik betroubare weergawe van Jesuswoorde beskou, veral vers 14. 'n Maklike oorsig oor dié kwessie is te vinde by F W Funk \& R W Hoover (eds), The five Gospels: the search for the authentic words of Jesus (New York 1993), 89-90. Kyk ook R Pesch, Das Markusevangelium. 2. Teil: Kommentar zu Kap. 8,27-16,20 (Freiburg 1977), 133 se begronding van die historisiteit van dié Jesuswoord. J D Crossan, "Jesus and the gospel", in The biblical heritage in modern catholic scholarship, edited by J J Collins \& J D Crossan (Wilmington 1986), 106-30 verskil; volgens hom is EvThom 22.1-4 die ouer woorde wat deur Mk aangepas word. Hierdie tipe historiese ondersoek - wat outentieke oorspronge konstrueer - is uiters problematies met weinig interpretatiewe waarde. Ek verwys na Marc Bloch se kritiek op hierdie soort geskiedskrywing: "what a curious contradiction there is in the attitudes of so many historians: when it is a question of ascertaining whether or not some human act has really taken place, they cannot be sufficiently painstaking. If they proceed to the reasons for that act, they are content with the merest appearance, ordinarily founded upon one of those 
maxims of commonplace psychology which are neither more or less true than their opposites", Marc Bloch, The historian's craft (Manchester 1954), 195.

Vroeër is dié gedeeltes selfs beskou as sinspelings op die kinderdoop: $O$ Cullmann, Baptism in the New Testament (London 1950), 76-80 ('n eersteeeuse doopformule kan in Mk 10.13-16 bespeur word). Die siening is heeltemal cordrewe; kyk die kort maar sinvolle bespreking van J D G Dunn, Unity and diversity in the New Testament: an inquiry into the character of earliest Christianity (London 1977), 160-61.

3 'n "Kingdom of nobodies" - J D Crossan, The historical Jesus: the life of a Mediterranean Jewish peasant (Edinburgh 1991), 266-69, met die klem op die Thomasevangelie se parallelle met hierdie Jesustradisie.

4 So gesien is die vertelling 'n opdrag om radikaal en konsekwent vogens die “Prinzip der Umkehrung aller Dinge im kommenden Äon zu handeln", te wete die afwys van aansien, mag, rykdom en sekerheid; Pesch, Markusev. 2, 13234. Hierdie interpretasie maak nogal sin binne die verband van die Markaanse vertelling; vergelyk die omliggende gedeeltes in Markus 9 en 10.

5 Joachim Jeremias, New Testament theology: the proclamation of Jesus (New York 1971), 109-13, 156, 227-28.

6 J D M Derrett, "Why Jesus blessed the children (Mk 10:13-16)", Novum Testamentum 25 (1983), 1-18.

7 Die sinspeling is op L DeMause, "The evolution of childhood", in The history of childhood, edited by L DeMause (New York 1974), 1: "The history of childhood is a nightmare from which we have only recently begun to awake." Kyk ook die beknopte oorsig van J Louise Despert, The emotionally disturbed child: an inquiry into family patterns (Garden City 1970), 27-100.

8 Alhoewel dit 'n ouer werk is, is Peter L Berger \& Thomas Luckmann, The social construction of reality: a treatise in the sociology of knowledge (Harmondsworth, 1967), 65-67, 75-80, 145-93 nog altyd die moeite werd om in hierdie verband te raadpleeg; kyk ook Erika Bourguignon, Psychological anthropology: an introduction to human nature and cultural differences (New York 1979), 116-59. Familielewe en persoonlike ervaring/ontwikkeling is 'n ingewikkelde saak; kyk, o.a., Lynn Jamieson, “Theories of family development and the experience of being brought up", Sociology 21, no 4 (1987), 591-607. $P$ Ariès, Centuries of childhood (London 1996), 13-47, 125-30, 353-99; Roger Cox, Shaping childhood: themes of uncertainty in the history of adult-child relationships (London, 1996), 1-10; R Lachmann, "Kind", Theologische Realenzyklopädie 18 (1989), 156-76 (p 156).

10 P L Berger \& Brigitte Berger, The war over the family: capturing the middle ground (Harmondsworth 1983), 14-15.

11 Ek het in gedagte die betrokke artikels in die standaardnaslaanwerke: Interpreters Dictionary of the Bible, New Bible Dictionary, Zondervan Pictorial Encyclopedia of the Bible en Anchor Bible Dictionary. Dieselfde onkritiese en naïewe benaderingstyl is egter ook te bespeur by: A D Bouquet, Everyday life in New Testament times (London, 1953), 146-50, 156-62; I J Du Plessis, “Die sosiale en ekonomiese lewe van die Joodse volk in Palestina in die tyd van die Nuwe Testament", in Handleiding by die Nuwe Testament, 2: die leefwêreld van die Nuwe Testament, edited by A B Du Toit (Halfway House 1997), 319, 324 
26; H F Stander \& J P Louw, Gebruike en gewoontes in die Bybel (Vereeniging 1990), 62-64, 83. Kyk ook Daniel-Rops, Daily life in Palestine at the time of Christ (London, 1962), 101-14; J E Stambaugh \& D L Balch, The New Testament in its social environment (Philadelphia 1986), 84. Omtrent niksseggend is V H Matthews, Manners and customs in the Bible (Peabody, 1991), 225-32. J D Crossan, Jesus: a revolutionary biography (New York 1994), 64, vermeld darem die "horrifying meaning of a child as a nothing, a nobody, a nonperson in the Mediterranean world of paternal power, absolute in its acceptance or rejection of the newly born infant".

12 Dié "romantiserende" uitbeeld van die antieke kinderlewe as 'n soort van gebruik van historiese gegewens is waarskynlik 'n goeie voorbeeld van "alwaysalready-read" tekste, wat deur "sedimented layers of previous interpretation" oftewel "through the sedimented reading habits and categories developed by those inherited interpretive tradiditions" bekyk word. Kyk F Jameson, The political unconsciousness: narrative as a socially symbolic act (Ithaca 1981), 9. Vergelyk ook J C Sommerville, The rise and fall of childhood (Beverly Hills, 1982), 11 en H E Faber van der Meulen, 'WWorden als een kind'. Als welk kind?" Hervormde Teologiese Studies 52 (1996), 351-75 (p 353).

13 H-R Weber, Jesus and the children: Biblical resources for study and preaching (Geneva 1979), 9.

14 Tasitus gebruik beskrywings soos: absurdus sordidusque, sinistra foeda en pravitate valuere - Hist 5.5 .

15 P Laslett, The world we have lost (London 1965), 104, herrinner ons aan die "crowds and crowds of little children... strangely missing from the written record... There is something mysterious about the silence of all these multitudes of babes in arms, toddlers and adolescents in the statements men made at the time about their own experience... It is in fact an effort of mind to remember all the time that children were always present in such numbers in the traditional world, nearly half the whole community living in a condition of semiobliteration". "Just as most children's lives do not reflect the enormous importance we accord childhood today, the child of history stands paradoxically at the center of human society and at its margin", P L Safford \& E J Safford, $A$ history of childhood and disability (New York 1996), 1.

16 Margaret Mead, "Theoretical setting", in $M$ Mead \& $M$ Wolfenstein (eds), Childhood in contemporary cultures (Chicago 1955), 3-5.

17 "Women have heretofore been defined out of history... They have been so delineated as to be removed from the historian's past. Women have been seen principally $b$ in roles that by their nature seem to be timeless and therefore outside history", C Degler, Is there a history of women? (Oxford, 1975), 6. Vervang "women" met "children" en die probleemstelling van my artikel is aan die orde. Ek beklemtoon dat hierdie artikel ' $n$ inleiding tot en ' $n$ verkenning van die problematiek is.

18 J Sharpe, "History from below", in New perspectives on historical writing, edited by P Burke (University Park 1991), 25; P J J Botha, "Paul and gossip: a social mechanism in early Christian communities", Neotestamentica 32, no 2 (1998), 267-88 (pp 267-69, 284-85).

19 Let op die inleidende paragrawe van Sharpe, "From below", 24-27. Peter Burke, "Overture: the new history: its past and its future", in New perspectives 
on historical writing, edited by P Burke (University Park 1991), 1-23 is 'n goeie inleiding tot die sogenaamde "nuwe geskiedskrywing".

20 E Thompson, The making of the English working class (Harmondsworth 1968), 12-13. "History from below helps convince those of us born without silver spoons in our mouths that we have a past, that we come from somewhere", Sharpe, "From below", 38.

21 De civitate Dei 21.14. Waar moontlik het ek die Loeb Classical Library gebruik wat betref antieke skrywers, andersins, vir sommige Griekse skrywers, die Thesaurus Lingua Graecae, Packard Humanities Institute, University of California. Ander teksuitgawes word aangedui. Vertalings is my eie.

22 Augustinus verwys op verskillende plekke na die vreesaanjaende kinderjare wat hy ervaar het (bv, Conf 1.9). In 1.13 van sy Belydenisse vertel Augustinus hoe haatlik onderrig was; cf, in verband met skole in Augustinus se dae, J B Ross, "The middle-class child in urban Italy, fourteenth to early sixteenth century" in L deMause (ed), The history of childhood (New York 1974), 213-15. P Brown, Augustine of Hippo (Berkeley 1967), 28-29, 36-37, 171, 352 bespreek aspekte van Augustinus se kinderjare. Brown beklemtoon die tipiese van Augustinus se opvoeding.

23 Flagellum en flagellare kom 495 keer voor in Augustinus se geskrifte; T S de Bruyn, "Flogging a son: the emergence of the pater flagellans in Latin Christian discourse" Journal of Early Christian Studies 7 (1999), 250 n 6. Augustinus se God het maar "gedugte genade" (seuera misericordia, Conf 2.2.4, o a) en lyding, swaarkry en liggaamlike pyniging is alles deel van Gods "liefde". Wanneer God selfs die "goeie gelowige" straf, doen Hy maar net wat enige goeie pa doen.

24 Daar is heelwat goeie literatuur hieroor; kyk veral K C Hanson, "Kinship", in The social sciences and New Testament interpretation, edited by R L Rohrbaugh (Peabody 1996), 62-79; P Laslett, "The history of the family", in P Laslett \& $\mathrm{R}$ Wall (eds), Household and family in past time (Cambridge 1972); J H Neyrey, "Ancestors", The Collegeville Pastoral Dictionary of Biblical Theology (1996), 22-24; C Osiek \& D L Balch, Families in the New Testament world: households and house churches (Louisville 1997); Miriam Peskowitz, "'Family/ies' in antiquity: evidence from Tannaitic literature and Roman Galilean architecture", in The Jewish family in antiquity, edited by S J D Cohen (Atlanta 1993), 9-36; R P Saller, "Familia, domus, and the Roman conception of the family", Phoenix 38, no 4 (1984), 336-55; John E Stambaugh, The ancient Roman city (London 1990), 158-61; S Safrai, "Home and family", in S Safrai \& M Stern (eds), The Jewish people in the first century: vol 2 (Philadelphia 1976), 748-64. 'n Oorsig oor die stand van die ondersoek wat die historiografie van die familie betref is te vinde by Lawrence Stone, "Family history in the 1980s", Journal of Interdisciplinary History 12 (1981), 51-87.

25 Mark McVann, "Family-centredness", in J J Pilch \& B J Malina (eds), Biblical social values and their meaning: a handbook (Peabody 1993), 70-73.

$26 \mathrm{~J}$ Boswell, The kindness of strangers: the abandonment of children in western Europe from late antiquity to the renaissance (London 1988), 429: "it would require extraordinary circumstances... to render children valueless to anyone in such a society"; T F Carney, The shape of the past: Models and antiquity 
(Lawrence 1975), 198-200 ("The peasant life style"). In verband met arbeid en kostes in 'n agrariese kultuur: G Lenski, J Lenski \& P Nolan, Human societies: an introduction to macrosociology, 6th edition (New York 1991), 181-85. Lenski beklemtoon dat vanuit die aristokrasie se oogpunt is daar altyd nóg bediendes beskikbaar; my klem is anders, vir die kleinboere is oorlewing baie moeilik.

27 Baie kinders en die oorlewing van families: A L Laffey \& J H Neyrey, "Family", The Collegeville Pastoral Dictionary of Biblical Theology (1996), 306-11 (p 306). 'n Beknopte corsig van antieke demografiese faktore: P J J Botha, "Health and healing in New Testament times: historical understanding and the health care debate", Health SA Gesondheid 1, no 2 (1996), 3-11. Kyk verder: Carney, Shape, 87; W T Sanders, "Pre-industrial demography and social evolution", in On the evolution of complex societies, edited by T Earle (Malibu 1984), 7-39.

28 A E Imhof, "The implications of increased life expentancy for family and social life", in W Wear (ed), Medicine in society: historical essays (Cambridge 1992), 347-76.

29 S Guijarro, "The family in first-century Galilee", in Constructing early Christian families: family as social reality and metaphor, edited by $\mathrm{H}$ Moxnes (London 1997), 57-61.

30 ' $n$ Kritiese teks en (redelike) inleiding is te vinde by: $H \quad R$ Smid, Protevangelium Jacobi: a commentary (Assen 1965). Uiteraard moet sulke narratiewe tekste met omsigtigheid hanteer word vir die ontginning van sosiale geskiedenis; kyk die waardevolle opmerkings van F G Downing, "A bas les Aristos'. The relevance of higher literature for the understanding of the earliest Christian writings", Novum Testamentum 30 (1988), 212-30. Sulke literatuur reflekteer nie die werklikheid nie, maar refrakteer dit - dog is dit bronne van ongekende waarde: R Alter, "Literary refractions of the Jewish family", in The Jewish family: metaphor and memory, edited by D Kraemer (New York 1989), 224-25.

31 Daar is veel meer as "verleentheid" op die spel hier: 'n kragtige, diepgesetelde kompleks van negatiewe emosies en belewenisse ( $T$ J Scheff, "Thick description: basic issues in interpretive science”, in D R Maines \& C J Couch (eds), Communication and social structure (Springfield 1988), 259-60). Dit is met goeie rede dat Lukas (1.6) beklemtoon dat Elisabet en Sagaria wetsgetroue en onberispelike gelowiges was; hulle kinderloosheid was destyds 'n sprekende bewys van die teenoorgestelde (cf J A Fitzmyer, The gospel according to Luke (I-IX): introduction, translation and notes, Achor Bible 28 (Garden City 1981), 323). Kyk ook J Schaberg, The illegitimacy of Jesus: a feminist theological interpretation of the infancy narratives (Sheffield 1995), 103-4. Meer oor "smaad" (reproach, shame): B J Malina \& J H Neyrey, "Honor and shame in Luke-Acts: pivotal values of the Mediterranean world", in The social world of Luke-Acts: models for interpretation, edited by J H Neyrey (Peabody 1991), 2565.

32 Psalm 127.3, Wysheid van Sirag 22.3. Josefus noem dat 'n vrou wat verkeerdelik deur haar man aangekla word van ontrouheid, tien maande later 'n seun in die wêreld sal bring ( $A J 3.271$ ). Meer uitvoerige bespreking hiervan: $\mathrm{R}$ 
S Kraemer, "Jewish mothers and daughters in the Greco-Roman world", in The Jewish family in antiquity, edited by S J D Cohen (Atlanta 1993), 101-10; L J Archer, Her price is beyond rubies: the Jewish woman in Graeco-Roman Palestine (Sheffield 1990), 17-28.

33 Die inskripsie is te vinde by $\mathrm{H} \mathrm{J}$ Leon, The Jews of ancient Rome (Philadelphia 1960), 264. Soortgelyke Joodse inskripsies vanuit Egipte wat die dood van jong kinders herdenk: W Horbury \& D Noy, Jewish inscriptions of Graeco-Roman Egypt (Cambridge 1992), nommers 93, 96, 102, 103, 132.

34 "Documenting parental affection is somewhat like documenting the existence of parents - i e, impossible because nearly all documents are apposite”, Boswell, Kindness, 37 n 86.

35 Talle studies vermeld hoe tipies dit is van kleinboergemeenskappe dat babas gebore word op onverwagse momente. Byvoorbeeld: "It is not to be wondered at that now and again such cases occur; the peasant women move about outside so care-free although they are already in the last stage of pregnancy. It harmonizes very well with the nature of the fellaheen to leave too much to chance and not make arrangements for a birth in time. With their total lack of forethought they let themselves quite calmly be taken unawares by something of which they know the natural course months before. Their hard life full of heavy work does not allow them to spare themselves", Hilma Granqvist, Birth and chlidhood among the Arabs: studies in a Muhammedan village in Palestine (Helsingfors 1947), 55. Babas is dikwels by die baddens, op die markpleine of oppad êrens gebore, B Leyerle, "Appealing to children" Journal of Early Christian Studies 5 (2, 1997), 246.

36 Die basiese tekste wat ek geraadpleeg het is m.Niddah, t.Ketubbot en (GrieksRomeinse bronne) Soranus $\Gamma \nu \nu \alpha \iota \kappa \varepsilon \hat{\imath} \alpha$, Galenus $\Pi \varepsilon \rho \grave{\imath} \phi v \sigma \kappa \hat{\omega} \nu \delta v \nu \alpha \dot{\mu} \varepsilon \omega \nu$, De usu partium. Bespreking: Archer, Her price, 17-68; L M Epstein, Sex laws and customs in Judaism (New York 1967), passim; D M Feldman, Birth control in Jewish law: marital relations, contraception, and abortion as set forth in the classic texts of Jewish law (New York 1968), passim; Safrai, "Home and family", 764-73. Waardevolle kruis-kulturele inligting by $S$ Goitein, $A$ Mediterranean society. The Jewish communities of the Arab world as portrayed in the documents of the Cairo Geniza, 3: the family (Berkeley 1978), 223-50; Granqvist, Birth; A M Lutfiyya, Baytîn, a Jordanian village: a study of social institutions and social change in a folk community (The Hague 1966), 129-67; J Morgenstern, Rites of birth, marriage, death and kindred occasions among the semites (New York 1973). Kyk ook Shulamith Shahar, Childhood in the Middle Ages (London 1990).

37 Een van Mildred Dickeman, "Demographic consequences of infanticide in man”, Annual Review of Ecology and Systematics 6 (1975), 107-37 se mees versoberende bydraes is haar bespreking van die rol wat kindermoord speel in die manipulasie van geslagsgetalle (sex ratios). Regdeur die antieke wêreld het daar te alle tye meer mans as vrouens in alle sosiale strata gelewe. Dit is 'n merkwaardige verskynsel, veral as ons in gedagte hou dat meer mans (as vegters) as vrouens in oorloë gesterf het, en dat, biologies bekyk, word meer dogters as seuns gebore. Sarah B Pomeroy, Goddesses, whores, wives and slaves (New York 1975), 40-41, 46, 69-70, 127, 140, 227-228, redeneer dat 
die beste verklaring hiervoor babadogtermoord is. Kyk ook S B Pomeroy, "Infanticide in Hellenistic Greece", in A Cameron \& A Kuhrt (eds), Images of women in antiquity (London 1983), 207-222. Wat belangrik is in Pomeroy se perspektief is dat sy nie die indrukke ("images") wat mans deur middel van kuns en literatuur nagelaat het, wil ondersoek nie maar die "realities of women's existence", Goddesses, 229. 'n Histories-vergelykende studie: E Voland, "Human sex-ratio manipulation: historical data from a German parish", Journal of Human Evolution 13 (1984), 99-107).

38 Aline Rouselle, Porneia: on desire and the body in antiquity (Oxford 1988), 50-51; Dickeman, "Demographic consequences", 117-20; Susan C M Scrimshaw, "Infanticide in human populations: societal and individual concerns", in Infanticide: comparative and evolutionary perspectives, eds G Hausfater \& S B Hrdy (New York 1984), 445-46.

39 Oor hierdie dramatiese en ontnugterende aspek van ons geskiedenis: W L Langer, "Infanticide: a historical survey", History of Childhood Quarterly 1 (1973-74), 353-65; Boswell, Kindness.

40 Tekste wat gewoonlik aangehaal word is: Filo De specialibus legibus 3.108119, Josefus Contra Apionem 2.202; Sibillynse Orakels 3.765-766; Tasitus Historiae 5.3. Rabbynse veroordeling van kindermoord: b.Yoma 85b. Voorbeelde vanuit vroeg-christelike literatuur: Didage 2.2, 5.2; Brief van Barnabas 19.5; Apokalips van Petrus 8.

41 Die blote feit dat daar waarskuwings en veroordelings in die literatuur voorkom is mos al klaar 'n erkenning. Dit is absurd om te redeneer dat iets wat in Joodse literatuur veroordeel word, nie onder Joodse mense voorgekom het nie (immers, moord, diefstal, homoseksualiteit en huweliksontrou word ook verbied/negatief beskou, en niemand dink dat dit nie gebeur het nie). Dit is ook opvallend dat Filo en Josefus verskil oor hoe Eksodus 21.22-23 verstaan moet word Josefus ( $A J$ 4.278), anders as Filo, sien die geforseerde miskraam as 'n wandaad aan die moeder en die boete moet betaal word aan haar man. In Contra Apionem skryf Josefus dat 'n vrou wat 'n aborsie bewerk of 'n fetus weggooi as 'n "kindermoordenaar" beskou word. Hy noem, opvallend genoeg, geen straf nie. Die rabbis beskou die doodmaak van 'n baba as moord, maar "baba" beteken "minstens een dag oud" ( $m$.Nidda 5.3)- 'n nie onbelangrike kwalifikasie nie, wat nogal ruimte bied vir "menslike diskressie". Aborsie is natuurlik wel toegelaat wanneer die mammie se lewe in die gedrang kom: "wanneer 'n vrou baie swaar kraam, moet die kind in haar baarmoeder opgesny word en lidmaat vir lidmaat uitgehaal word, want die lewe van die ma het voorkeur bo die lewe van die kind" (m.Ohalot 7.6). Maar as die kind se kop reeds heeltemal sigbaar is, mag niks meer gedoen word nie omdat die een se lewe nie meer is as die ander s'n nie. Ek verwys ook na die sensus van Joodse families in Arsinoe (Egipte) van die jaar 73, vir belastingdoeleindes, wat 'n besonder opvallende tekort aan kinders weerspieël (Corpus Papyrorum Judaicorum 421). Die redakteurs (V A Tcherikover \& A Fuks, p 205) vermoed dat blootstelling van kinders 'n rol gespeel het - so ook Kraemer Jewish mothers, 108. Laastens, in al die besprekings oor die baba wie se lewe beskerming behoort te geniet, is die veronderstelling dat dit handel oor die welgeskape baba. 
Ek vermoed dat die (middeleeuse) legendes oor God wat vir onskuldige babas sorg deur middel van wonderwerke (kyk, o a, Sefer ha-yashar (M Noach, The book of Jaschar (New York 1972), Shemot Rabbah (of Eksodus Rabbah, in die Soncino uitgawe, Midrash Rabbah vol 3) - oor Moses; b. Sotah 11b) soos Europese "sprokies" verstaan moet word: volksvertellinge wat aaklige werklikhede uitbeeld ("Hansie en Grietjie").

43 J D M Derrett, Jesus's audience: the social and psychological environment in which He worked (London 1973), 31-38.

44 Cf F W Knobloch, $s v$ "Adoption", $A B D 1$ (1992).

45 "The striking conclusion that emerges... is that the Jewish family in antiquity seems not to have been distinctive by the power of its Jewishness; rather, its structure, ideals, and dynamics seem to have been virtually identical with those of its ambient culture(s)", S J D Cohen, "Introduction", The Jewish family in antiquity (Atlanta 1993), 2 en verwysings daar.

46 Oor Joodse slawe: Z W Falk, Introduction to Jewish Law of the second commonwealth, part 2 (Leiden 1978), 263-68; D A Fiensy, The social history of Palestine in the Herodian period (Lewiston 1991), 90-92; P V M Flesher, Oxen, women, or citizens? Slaves in the system of the Mishnah (Atlanta 1988); Dale B Martin, "Slavery and the ancient Jewish family", in The Jewish family in antiquity, edited by S J D Cohen (Atlanta 1993), 113-29. Die befaamde onderskeid tussen (beperkte) menslike arbeid koop en volle besit van die liggaam wat betref Joodse slawe ( $\mathrm{d}$ w s 'n Jood koop net arbeid as hy 'n Joodse slaaf koop) moet nie te ernstig opgeneem word nie; kyk Flesher, $a w, 36$ en Martin $a w, 115-17$.

47 Z Safrai, The economy of Roman Palestine (London 1994), 248, 260.

48 Cf Leyerle, "Appealing”, 245.

49 L W Countryman, Dirt, greed and sex: sexual ethics in the New Testament and their implications for today (Philadelphia 1988), 147-56; D C Duling, "Matthew's plurisignificant 'Son of David' in social science perspective: kinship, kingship, magic, and miracle", Biblical Theology Bulletin 22 (1992), 99-116 (p 111); R Hamerton-Kelly, God the Father: theology and patriarchy in the teaching of Jesus (Philadelphia 1979), 55-70; F Horst, "Segen und Fluch", Religion in Geschichte und Gegenwart 5 (1961), 1559-62 (p 1560); Langer, "Infanticide: a historical survey", 363 n 7; V C Matthews \& D C Benjamin, Social world of ancient Israel 1250-587 BCE (Peabody 1993), 10.

50 T Canaan, "The child in Palestinian Arab superstition", Journal of the Palestine Oriental Society 7 (1927), 159-86 (p. 163).

51 Bruide het soutkristalle aan die kopbedekking vasgemaak om listige geeste (wat veral belangstel in jong bruide) af te skrik, asook om die bose oog te besweer (Archer, Her price, 193). Kyk ook die bespreking onder $\S 4.3$.

52 Margaret Mead, "The swaddling hypothesis: its reception", American Anthropologist 56 (1954), 395-409.

53 DeMause, “The evolution of childhood", 37, 67 n 205.

54 Tractatus 2.30-33. Teks: B Löfstedt (ed), Zeno Veronensis Tractatus. Corpus Christianorum SL 22 (Turnhout 1971). Van Zeno (c. 362-375) self weet ons maar min.

55 Cf Canaan, "Child", 174-5. 
56 Valerie A Fildes, Breasts, bottles and babies: a history of infant feeding (Edinburgh, 1986), 3-39, 60-61, 307-21.

57 M Broshi, "The diet of Palestine in the Roman period - introductory notes", Israel Museum Journal 5 (1986), 41-56 (pp. 48-49); G Hamel, Poverty and charity in Roman Palestine, first three centuries C.E. (Berkeley 1990), 19, 2627.

58 Leyerle, “Appealing”, 250-51;

59 Slegs 50\% van babas het die eerste vyf lewensjare oorleef: Bruce Frier, "Roman life expectancy: Ulpian's evidence" Harvard Studies in Classical Philology 86 (1982), 213-51; eadem, "Roman life expectancy: the Pannonian evidence" Phoenix 37 (1983), 328-44; Keith Hopkins, "On the probable age structure of the Roman population" Population Studies 20 (1966), 245-66; T Canaan, "The child in Palestinian Arab superstition" Journal of the Palestine Oriental Society 7 (1927), 185.

60 John G Gager, editor, Curse tablets and binding spells from the ancient world (New York, 1992), 205-07, 226-32; E M Yamauchi, “Magic bowls”, Biblical Archaeologist 59, no. 1 (1996), 51-55; J Neusner, A history of the Jews in Babylonia 5 (Leiden, 1970), 218-35. "Jews used magical bowls as a domestic prophylactic”, Neusner, History 5, 175.

61 J Trachtenberg, Jewish magic and superstition (Philadelphia 1961), 35-37. Cf. J Neusner, History 5, 237.

62 4Q510.7. G G Martinez (ed), The Dead Sea Scrolls translated: the Qumran texts in English (Leiden 1994), 371.

63 Kyk Orationes 5.16-18. Dio Chrysostomus (40-112) noem die soort van verhaal 'n $\mu \hat{v} \theta 0 \varsigma$; kinders word weerhou van dinge met behulp van $\tau \grave{\alpha}$ $\mu о \rho \mu о \lambda \cup \kappa \varepsilon i \alpha$. Elders, in 'n terloopse opmerking, sê Dio dat hy glo elke kind het 'n eie skrikduiwel, en dat sommige seuns van nature bangerig is en sal huil maak nie saak waarmee mens hulle intimideer nie (66.20).

64 Met verloop van tyd het Lilith talle "susters" bygekry: Neusner, History 5, 235-6; Gager Curse tablets, 229 n 17

65 Jeremias, New Testament theology: the proclamation of Jesus, 93-94; E P Sanders, The historical figure of Jesus (London 1993), 141-43, 149; Safrai, "House and family", 766.

66 Vergelyk B Kaplan, "Anxiety states", in Adult psychopathology: a social work perspective, edited by F J Turner (New York 1984), veral 270-71.

67 R J Thomlison, "Phobic disorders", in Adult psychopathology: a social work perspective, edited by F J Turner (New York 1984), 280-315.

$68 \mathrm{Y}$ Yadin, The finds from the Bar Kochba period in the cave of letters (Jerusalem 1963), 256-58, fotobeelde 89-90.

$69 \quad$ m.Yoma 1.8, 2.1; Josefus $B J 1.331,377$; $A J$ 18.284-88; om maar net enkele voorbeelde te noem. Kyk ook Canaan, "Child", 164; Derrett Audience, 11623.

70 Josefus $A J$ 1.156, 167-8; $B J$ 6.289; b. Shabbat 156b. Kyk veral J H Charlesworth, "Jewish astrology in the Talmud, Pseudepigrapha, the Dead Sea Scrolls, and early Palestinian synagogues", HThR 70 (1977), 183-200; J H Charlesworth, "Jewish interest in astrology during the Hellenistic and Roman period", $A N R W 2.20 .2$ (1987), 927-49. 
71 Die "wetenskap" van gematria. J Friberg, $s v$ "Numbers and counting", $A B D$ (1992); R H Mounce, The Book of Revelation (Grand Rapids 1977), 263-65.

72 Archer, Her price, 40-42. Kyk ook Derrett, Audience, 119; J Z Lauterbach, Studies in Jewish law, custom and folklore (New York 1970), 30-32.

73 1 Samuel 25.25; Gn 27.36.

74 G H R Horsley, $s v$ "Names, double" $A B D$ (1992); D M Piker, $s v$ "Names, theophoric" ABD (1992).

75 Cf J Casey, The history of the family (London 1989), 162.

76 Let, in hierdie verband, op die belangrike opmerkings by DeMause, "Evolution of childhood", 17. 